\title{
Study on the Formation and Influence Factors of the Coal Bed Gas in Bo
}

\author{
Li Basin \\ Jingying $\mathrm{Li}^{1, \mathrm{a}}{ }^{*}$, a,Haihang Zhang ${ }^{2, \mathrm{~b}}$ \\ ${ }^{1}$ (Northeast Petroleum University, Daqing Heilongjiang China) \\ ${ }^{2}$ (552 oil crew,3rd oil production,No.7 factory, Daqing Oilfield Heilongjiang China) \\ a1090326020@qq.com
}

Keywords: Bo Li basin; Coalbed methane; Land sea interaction; Magmation

\begin{abstract}
Coal bed gas is gradually becoming an alternative choice as well as a clean energy for people' s live.Bo Li basin is rich in gas and it is the only district of the Northeast Mesozoic marine deposit of our nation,created favorable conditions for the formation of coal bed gas.Meanwhile, the coal bed gas is also under the influence of the tectonic movement and the magmation.. Various factors make the coal bed and coal bed gas develop in Bo Li basin, and easy to be developed and exploited.
\end{abstract}

\section{Introduction}

China is a coal producing country, and its coal reserves stands the second place, coal production ranks first of the world.Hei Longjiang province is a coal producing province.We began the geological survey of finding coal resources on Bo Li basin in the year of 1911[1].Bo Li basin was found the occurrence of coal mine bed about the year of 1956[2].Not alone the economic benefits the coal could bring,the coal bed gas also has huge potential economic benefits.It has been concerned by the world as a new type of clean alternative energy.In the early 80s, the United States made a breakthrough in the development and utilization of coalbed methane and gained the successful breakthrough of commercial development, led it became the new trend of the world to develop clean new energy[3].In the 21st century, China will face a more severe oil and conventional gas shortage situation and the enormous pressure of the ecological environment deterioration, it is imperative to find clean alternative energy and to prevent environmental pollution and coalbed methane is the best choice.Its industrial exploitation could lead the rapid development of the world's Coal bed gas industry.

\section{The development condition of the coal bed in Bo Li basin}

Boli basin is located in the eastern part of Hei Longjiang province,south to Wan Da mountain,north close to Ken Te mountain and the current area is 9020km2,the geographical coordinate is: longitude 130 degrees -132 degrees 30 minutes, between 45 degrees north latitude 30 degrees 25 '-46'[5].Bo Li Basin,among all of the eastern basins of Hei Longjiang Province, possess the features like early settling time,huge sedimentary thickness,frequent transgressive, wide range of 
transgression,strong volcanic activity. The evolution of sedimentary basin is controlled by tectonic evolution.

The particle size of the sediment generally from the bottom up is thinner in the vertical ; sedimentary environment has obvious differences in the plane, western part of the basin is mainly continental deposit, transitional facies are mostly found in the central, and marine sediments are mainly in the East.

The coal of Bo Li formed in the early Cretaceous, the Mesozoic coal formed in late Jurassic.Large amount of layers of coal seam exist in the basin, but the thickness is small, and the structure is simple to medium.The underlying strata layers of BoLi Basin coal strata are former Paleozoic, Paleozoic and Triassic .Jixi group is divided from the bottom up into Di Dao formation, Chengzihe formation, Muling formation, Dongshan formation, Longzhaogou group is divided from the bottom up into Pei De group, seven Hulin River group, Yunshan group. Chengzihe、Muling and Didao group of the Lower Cretaceous have coal accumulated.The thickness of coal totally measures as $2500 \sim 3700 \mathrm{~m}$.

\section{Generating environment of coal bed methane in Bo Li basin}

According to the data of the past, there are six kinds of facies in the area: residual slope product, alluvial fan, river, lake, fan delta, lake delta, etc.[6].Boli Basin alluvial fan is well developed, vertical profile has multi period of forming, and they normally distributed in the bottom of the formation, large alluvial fan are found at the bottom of the Pei Dezu, Didao and Chengzihe and Muling group.The lake sediments is widely distributed and could be seen in all continental sedimentary,especially developed in the upper part of the Muling and Chengzihe group.Lake delta is seen in the upper group and Chengzihe muling group. Didao group has a typical fan delta, it's alluvial fan directly into the lake formed, which occasionally contain marine fossils, and could see carbonaceous mudstone and thin coal layer. The delta deposition developed in Chengzihe layer, Zhushan, Yunshan group of the Boli basin is one the major sedimentary types and poly coal forming environment of the Heilongjiang Province .

In 1962, the Mesozoic-strata-team of Heilongjiang Province coal pipe Geological Bureaut found paralic strata in the east, made Boli Basin became the only marine deposits area of northeast China's Mesozoic.Land-sea interaction happens frequently in the region[7].The sedimentary facies types are complex and have unique features.From the horizontal perspective, central- western Boli Basin and the Jixi Basin are mainly coal containing continental sedimentary strata in the early and Middle Early Cretaceous,Eastern Boli Basin (Longzhaogou basin) development a set of marine - land-sea interaction with coal depositional sequence by the early Cretaceous marine transgression.In the vertical (Mesozoic) mainly exists two big stage of evolution, early stage is the Basin fault settlement stage, mainly Jixi group and Longzhaogou group coal bearing sedimentation.

Two transgression occurred in Heilongjiang Province in the eastern part of the late Early Cretaceous[8].During the transgression, with plate tectonics of marginal-Pacific occurring, the sea level changes occasionally.During the regression,may form a series of coastal marshes or intermontane lake basin,create advantages for forming the coal field.In the transitional area .

We can see from the evolution of the sedimentary system that,early Cretaceous has a wide range of transgression,shallow sea area mainly in east of longitude 132 degrees,north of 47 degrees 20 ' latitude,west of 130 degrees 45 minutes barely have transgression, which belongs to the continental environment.The middle zone of the these two is the coastal bay and the lagoon developing zone, 
and part of the area is delta and coastal plain.Flood plain generated coal in continental environment area.River Delta is the main coal accumulating environment of sea-land transition.Because of the fluctuation of sea water, the instability of the environment, the less development of the vegetation, cause the shortage of the source of coal material, only form the thin coal and coal line.

\section{Influence factors of coal bed gas}

Influence of tectonic movement on the formation of coal bed methane. Bo Li Basin's Basement has a plurality of anticline syncline, make the base is uneven as well as fault develops, establish the main structure of the basement of the basin,plays an important transforming role in the early tectonic and coal bearing construction.In the Cretaceous strata of the Bo Li basin, mainly developed tectonic block and characterized by a large number of tectonic deposits and normal faults.

Through the late Mesozoic fault depression and the tectonic movement of the Cenozoic basin during the period of the depression, the Bo Li basin is subjected to severe tectonic movement and received strong reconstruction[9].For instance,since the Neogene transformation stage, volcanic rocks distribute along the north-south trending faults that indicates, the district is mainly affected by the tectonic stress field of the north-south direction, and leading the magma eruption and the fault tension on north-south direction.

The influence of magma activity on the formation of coalbed methane. The Mesozoic Magmatic Activity in the eastern part of Hei Longjiang province is frequently and strongly.Lava accumulation is seen in Pei De, Yunshan and Didao group, and volcano clastic sedimentary rocks are distributed in every group like Jixi group, Longzhaogou group.The lava accumulation development shows that the late Mesozoic fault and volcanic activity of the study area were intense and frequent.The Mesozoic and Cenozoic magmatic rocks of the Boli basin are important parts of the volcanic rocks in the eastern part of China.Mesozoic Magmatic Rocks in Boli Basin not only widely distributed in the mountain area, is also widely distributed in the sedimentary strata of Mesozoic fault basin[10].

Several thermal events happened during the formation of the basin. Since the late Yanshan movement, in eastern Heilongjiang magmatic activities form small scale of stock and hypabyssal intrusive sills and dykes, in addition the granite porphyry, diorite porphyrite.These eruptions generally have little effect or could be said as " thermal cover" to be favorable preservation conditions, and may also promote the thermal evolution of organic matter.Magma upwelling, and emitted from the surface in staging times, forming volcanic rocks, volcanics, pyroclastic rock intrusion into the shallow crust of the earth intrusion into the rock mass, and geothermal gradient of the retroarc basin district increased.Just because this reason causing the abnormal high temperature that make the studying area is affected by the high temperature and the rapid metamorphism since Mesozoic coal formed.

Due to the magma activity, metamorphic grade of coal has such characteristics on the surface, namely obvious zonation along the vertical direction, the vitirnite reflectance of the coal showed regular changes with increasing of the depth. It also illustrates the quality of coal is under significant influence by regional metamorphism . 


\section{Conclusions}

(1) Bo Li Basin as a Mesozoic sea land interaction phase containing coal basin, coal containing seam group mainly are Chengzihe and Didao group, a total of more than 100 layers of coal. Coal reserves is considerable, so as the coal bed gas .

(2)Through studying the Bo Li basin,the area which contains coal acts intensely, the magma activity is frequent, and it is not suitable for the exploitation of the coal bed gas resources and the ground drilling.

(3)Bo Li Basin, while in the process of forming, its tectonic movement is intense, causing the eruption of magma, formed obvious magmatic sedimentary, and hydrothermal transformation are happened in the sediments at that time, not to mention a certain metamorphism influence on

coalbed methane.

(4)Bo Li basin is rich in coal bed gas, coal bed gas is a kind of great potential resource, and suitable for exploitation.

\section{References}

[1]Hood A et al.Organic metamorphism and the generation of petroleum,A.A.P.G.Bulletine. $1975 ; 59(6)$

[2]]Levine J.R.Coalification::The evolution of coal as source and reservoir.In:Law BE,Rice.D.D.ed..Hydrocarbons from coal,AAPG Studies in Geology\#38:39 78

[3]Schraufnagel,R.A.,Coalbed methane Production In:Law,B.E.,

,Rice,D.D.(eds),Hydrocarbons from Coal,AAPG Studies in

Geology 38,1993

[4]Morales,H.,Davidson,5.,Holdings,M.I.M,,Analysis of coalbed methane hydraulic fracturing behavior in the Bowen

Basin(Australia).In:Proceedings of the 1993 International

Coalbed Methane symposium.The University of Alabama/Tusealoosa,1993.

[5]Clayton,J.L.,Geochemistry of coalded gas - A review.International Journal of Coal Geology, 1998.

[6]Prat T.J, Mavor M.J,DeBruyn R.P.1999.Coal gas resource and production potential of subbituminous coal in the Powder River Basin.In:Proceedings of the 1999 International Coal一bed Methane Symposium,Tuscaloosa,

U.S.A. $23-34$.

[7]CAO Chen-run,SHAN Xuan-long,WANG Dong-po.The fault block' s framework in Bo Li Basin and its control

over the deposition [J].J Geosci NE Asia,2001,4(1):13-19.

[8]YUAN Jiang-ying,ZHOU Yan-ru,LI Xiang-bo,et al.Structural analysis and petroleum geology assessment of relic basins[J].Oil \& Geology，2000,21(1): 13-18。 2008,08-0126-02. 
[9]Zhai Guangming.Petroleum geology of China(N0.2 Daqing oilfield)[M].Beijing:Petroleum Industry Press, 1987:775-777.

[10]]Parker RL.The rapid calculation of Potential anomalies[J] • Geophysics Jour Roy 92 